\title{
ETHzürich
}

\section{Is the enzymatic hydrolysis of soil organic phosphorus compounds limited by enzyme or substrate availability?}

\author{
Journal Article \\ Author(s): \\ Jarosch, Klaus A.; Kandeler, Ellen; Frossard, Emmanuel; Bünemann, Else K. \\ Publication date: \\ 2019-12 \\ Permanent link: \\ https://doi.org/10.3929/ethz-b-000374879 \\ Rights / license: \\ Creative Commons Attribution-NonCommercial-NoDerivatives 4.0 International \\ Originally published in: \\ Soil Biology and Biochemistry 139, https://doi.org/10.1016/j.soilbio.2019.107628
}


This document is the accepted manuscript version of the following article: Jarosch KA, E Kandeler, E Frossard, EK Bünemann Is the enzymatic hydrolysis of soil organic phosphorus compounds limited by enzyme or substrate availability? Soil Biology and Biochemistry, doi.org/10.1016/j.soilbio.2019.107628

This manuscript version is made available via a CC BY-NC-ND 4.0 license: https:// creativecommons.org/licenses/by-nc-nd/4.0/

Originally uploaded to https://efrossard.ch/publications.html on 21 December 2019

Title:

Is the enzymatic hydrolysis of soil organic phosphorus compounds limited by enzyme or substrate availability?

Authors and affiliations:

KA Jarosch ${ }^{1,2}$, E Kandeler ${ }^{3}$, E Frossard ${ }^{2}$, EK Bünemann ${ }^{2,4}$

${ }^{1}$ Institute of Geography, University Bern, Switzerland

${ }^{2}$ Group of Plant Nutrition, ETH Zurich, Switzerland

${ }^{3}$ Institute of Soil Science and Land Evaluation, Soil Biology Department, University of Hohenheim, Germany

${ }^{4}$ Research Institute of Organic Agriculture, FiBL Frick, Switzerland

Corresponding author:

Klaus A. JAROSCH, Institute of Geography, University of Bern, Hallerstrasse 12, 3012-Bern, Switzerland, 00413163185 57, klaus.jarosch@giub.unibe.ch

Highlights:

- Factors limiting soil organic P hydrolysis were determined for 10 different soils

- Combined enzyme activity and addition assays showed substrate or enzyme limitation

- Most enzymatic activity was associated to the soil solid phase

- Hydrolysis of non-phytate phosphomonoesters was substrate limited

- Hydrolysis of phytate and phosphodiesters was enzyme limited 
Key words:

Phosphatase, organic phosphorus, phosphorus characterisation, enzyme activity 


\begin{abstract}
The mineralization of soil organic phosphorus $(\mathrm{P})$ is catalysed by extracellular phosphatases that hydrolyse different non-phytate phosphomonoesters (e.g., sugar phosphates and nucleotides), inositol phosphates (e.g., phytic acids), and phosphodiesters (e.g., nucleic acids, phospholipids). The availabilities of both the organic $\mathrm{P}$ compound and the respective phosphatase enzyme jointly determine whether the hydrolysis reaction is substrate limited (enzyme availability > substrate availability) or enzyme limited (enzyme availability < substrate availability), with potential consequences for overall organic P composition and accumulation in soil. Our objective was to evaluate whether the hydrolysis of various organic $\mathrm{P}$ compounds in soil is limited by availability of substrate or enzyme. To this end, we combined the principles of enzyme activity assays and enzyme addition assays. Ten soils with contrasting properties and origins received either model organic $\mathrm{P}$ substrate, specific phosphatases or a combination of both, added either to a soil:water suspension or a soil:water filtrate. Soil indigenous activity of phosphatases was low in all filtrates, confirming that enzymes were mostly associated with the solid fraction of the soil. In soil suspensions, the rapid hydrolysis of added non-phytate phosphomonoester substrate by soil indigenous enzymes indicated high availability of non-phytase phosphomonoesterase enzymes. In combination with the low availability of non-phytate phosphomonoester substrate in soil suspensions, determined by adding enzymes to the suspensions, this indicated a substrate limitation for the hydrolysis of non-phytate phosphomonoesters in soil. In contrast, enzyme-limitation was found for phytate and phosphodiesters. A review of the available literature on the production, stabilization and hydrolytic activity of each of the three analysed organic $\mathrm{P}$ substrates and the respective enzymes supported our findings. We therefore suggest that not only the production and stabilization but also differences in available phosphatase enzymes strongly determine the occurrence of specific organic $\mathrm{P}$ compounds in soil.
\end{abstract}

\title{
1. Introduction
}

Between 20 and $80 \%$ of soil phosphorus (P) can be present in organic form (Harrison, 1987). The mineralization of organic $\mathrm{P}$ is catalysed by extracellular enzymes, in particular by phosphatase enzymes (Nannipieri et al., 2011) and results in the release of bioavailable orthophosphate. Phosphatases are grouped into different classes by the Nomenclature Committee of the International Union of Biochemistry and Molecular Biology, depending on the compounds they are able to hydrolyse. Phosphomonoesterases include acid and alkaline phosphomonoesterases which hydrolyse phosphomonoester bonds in compounds such as mononucleotides and sugar phosphates (EC 3.1.3). Another class of phosphomonoesterases are phytases, which hydrolyse the phosphate groups from (myo)inositol hexakisphosphate, also known as phytate (EC 3.1.3.8, EC 3.1.3.26, EC 3.1.3.72). 
Phosphodiesterases hydrolyse one or two ester bonds in phosphodiesters such as nucleic acids (EC 3.1.4).

Phosphatases are actively excreted by plants, fungi and microorganisms to satisfy their demand for orthophosphate (Tarafdar and Claassen, 1988; Macklon et al., 1997; Vance et al., 2003; Richardson et al., 2009). Several microorganisms and plants constitutively produce phosphatases and thus constantly release these enzymes into their environment (Weimberg and Orton, 1963; Allison and Vitousek, 2005). Production of phosphatases can also be induced by low available $\mathrm{P}$ concentrations and repressed by high P concentrations (Nannipieri, 1994; del Pozo et al., 1999; Wasaki et al., 2003). Enzyme activity is somewhat sustained when stabilized on soil mineral and organic surfaces (Burns et al., 2013). Ultimately, the active excretion of phosphatases or their release by cell lysis after death results in the build-up of indigenous soil phosphatase activity derived from plants, fungi and bacteria.

While the overall relevance of phosphatase enzymes for the hydrolysis of organic $\mathrm{P}$ is evident, the relative importance of specific phosphatases for soil organic $\mathrm{P}$ hydrolysis is unclear. Several factors determine the availability of both specific phosphatases and specific organic $\mathrm{P}$ compounds in soil; their release by soil biota and plants into soil and their degree of stabilization on the soil solid phase (Celi and Barberis, 2005; Datta et al., 2017). Additionally, enzymatic activity may change under different environmental conditions (e.g., temperature or $\mathrm{pH}$ ). The hydrolysis of soil organic $\mathrm{P}$ by phosphatases can be limited either by enzyme or substrate availability (Figure 1a). In an enzyme-limited situation, more substrate is available than the available enzymes are able to hydrolyse; this may lead to a build-up of substrate. Such an enzyme-limited situation was, for example, observed in peatlands, where the limited activity of phenol oxidase enzymes resulted in accumulation of organic carbon (Freeman et al., 2004). In a substrate-limited situation, more enzyme is available than the respective substrate, as recently detected for the depolymerisation of soil proteins (Noll et al., 2019). In the rare case that substrate availability equals enzyme availability, neither factor limits the enzyme-catalysed substrate hydrolysis. Thus, substrate-limited or enzyme-limited conditions in soil may influence the overall quantity and composition of soil organic $\mathrm{P}$.

Some studies have addressed the effects of different phosphatase activities on soil organic $\mathrm{P}$ mineralization and organic $\mathrm{P}$ composition. The potential activity of non-phytase phosphomonoesterases in several soils was higher than that of phosphodiesterases (Eivazi and Tabatabai, 1977; Dick and Tabatabai, 1984; Turner and Haygarth, 2005), suggesting a limitation of phosphodiester decomposition by low phosphodiesterase activity. A similar observation was made in a geosequence of beech forest soils with low to high P stocks, where soils with lowest P stocks showed the widest ratios of non-phytase phosphomonoesterase to phosphodiesterase (Lang et al., 2017). Reports on the mineralization rates of specific organic $\mathrm{P}$ compounds in soil likewise suggest that phosphodiesters and phytate are hydrolysed more slowly than non-phytate phosphomonoesters (Fransson and Jones, 2007; Doolette et al., 2010; 
Darch et al., 2014). In addition, the hydrolysis of organic P compounds is likely affected by spatial separation of enzymes and substrates, potentially resulting in only a small fraction of total soil organic $\mathrm{P}$ available for enzymatic hydrolysis. This concept is in accordance with the claim that stabilization of soil organic matter occurs through environmental and biological controls rather than through the inherent recalcitrance of soil organic matter fractions (Schmidt et al., 2011), but has not been tested specifically for soil organic $\mathrm{P}$.

Our objective was to evaluate whether the hydrolysis of various organic P compounds in soil is limited by substrate or enzyme availability. To this end, we combined the principles of enzyme activity assays and enzyme addition assays. In enzyme activity assays, an excess of substrate is added to a sample in order to quantify the activity of enzymes; the aim of enzyme additions is to characterize the availability of substrates for enzymatic hydrolysis (Bünemann, 2008). Our approach is shown in Figure 1b for the three main classes of organic $P$ substrates in soil that are hydrolysed by enzymes. First, the availability of a given organic $\mathrm{P}$ substrate for enzymatic hydrolysis is determined based on the increase in orthophosphate upon addition of the respective phosphatase enzyme. Second, the availability of indigenous enzymes to hydrolyse a given organic $\mathrm{P}$ substrate is derived from the increase in degradation product upon addition of the substrate to a sample. Third, both substrate and enzyme are added in order to exclude inhibition of added enzyme in the sample and to account for incomplete recovery of orthophosphate when working with P-sorbing samples such as soil:water suspensions. Last, the sample is incubated in the absence of any added substrate or enzyme to determine background orthophosphate levels. If the first assay indicates presence of hydrolysable substrate in the sample, comparison of the second and third assays makes it possible to distinguish enzyme-limited from substrate-limited hydrolysis. If addition of substrate alone or substrate and enzyme together yield similar recoveries of hydrolysis product, then substrate limitation is indicated.

We applied this approach to soil:water suspensions and soil:water filtrates. To date, enzyme addition assays have been applied mostly to soil:water filtrates, but soil:water suspensions more closely resemble indigenous conditions. Also, most indigenous enzyme activity is located on the soil solid phase and is thus excluded from filtrates. The soils studied here were previously characterized using ${ }^{31} \mathrm{P}$ nuclear magnetic resonance (NMR) spectroscopy and adding enzymes to alkaline soil extracts (Jarosch et al., 2015). This identified inositol phosphate $P$ as the largest identifiable organic $P$ class in most soils, followed by non-phytate phosphomonoesters ("monoester-like P", excluding yet unidentified monoesters (McLaren et al., 2019)). We hypothesized that the hydrolysis of phytate as a typically dominant soil organic P class is enzyme-limited, whereas the hydrolysis of less abundant organic P classes (non-phytate phosphomonoesters and phosphodiesters) is substrate-limited. This hypothesis was tested by conducting the assays in soil:water suspensions. In contrast, we expected hydrolysis of all organic P classes to be enzyme-limited in soil:water filtrates due to the generally low concentrations of 
enzymes in filtrates. Finally, we hypothesized that our approach of identifying a substrate limitation or enzyme limitation for the hydrolysis of specific organic P compounds in soil would be applicable to a wide range of soil types.

\section{Material and Methods}

\subsection{Soil origin}

Ten soils with different properties ( $\mathrm{pH}$, texture, $\mathrm{P}$ content), origin (Africa, Australia, Europe and South America), and land use (grassland and arable land) were used in this study (Table 1). The soils were airdried and passed through a $2 \mathrm{~mm}$ mesh sieve, except for Cambisol (2) for which a $0.5 \mathrm{~mm}$ sieve was used to remove coarse particles clogging the pipette tip when working with soil:water suspensions. Organic P in alkaline soil extract had been previously been characterised for these soils, together with some additional soil properties (Jarosch et al., 2015).

\subsection{Determination of enzyme or substrate limitations}

We determined whether organic $\mathrm{P}$ hydrolysis was limited by enzyme availability or substrate availability using both soil:water suspensions and soil:water filtrates. Suspensions or filtrates were incubated in four subsets; either 1) with addition of substrate specific enzymes, 2) with addition of specific organic $P$ substrates, 3) with addition of both substrate specific enzymes and substrate, or 4) without any additions (Figure 1b).

The substrate specific phosphatases used were; i) a phosphomonoesterase without phytase activity (acid phosphatase from potato, Sigma P1146, 50 units diluted in $15 \mathrm{ml} \mathrm{H}_{2} \mathrm{O}$ to reach a catalytic activity of $55.5 \mathrm{nkat} \mathrm{ml}^{-1}$ ), ii) a phytase from Peniophora lycii (Ronozyme ${ }^{\circledR} \mathrm{NP}$ (Novozyme), $550 \mathrm{nkat} \mathrm{ml}^{-1}$ ), and iii) a phosphodiesterase (nuclease from Penicillium citrinum, Sigma N8630, 0.167 mg diluted in $1 \mathrm{ml}$ $\mathrm{H}_{2} \mathrm{O}, 550 \mathrm{nkat} \mathrm{ml}^{-1}$ ). These enzymatic activities had previously been determined sufficient to hydrolyse added organic P model compounds in a similar setup for organic P characterisation in soil:water suspensions and soil:water filtrates (Annaheim et al., 2013).

The model organic $\mathrm{P}$ compounds used as specific organic $\mathrm{P}$ substrates in concentrations of $0.23-0.30$ mM P were; i) a phosphomonoester (glycerol phosphate disodium salt hydrate (GP), Sigma G6501), ii) phytate (phytic acid sodium salt hydrate (Ins6P), Sigma P8810), and iii) a phosphodiester (desoxyribonucleic acid from herring sperm (DNA), Sigma D3159).

Soil suspensions (two to three replicates for each soil) of $10 \mathrm{~g}$ dry soil with $100 \mathrm{ml}$ autoclaved deionized water were prepared in an overhead shaker for $16 \mathrm{~h}$. Soil suspensions were stirred vigorously during sampling to ensure homogeneous sample transfer. Soil filtrates were obtained from each soil suspension by filtering through a $0.2 \mu \mathrm{m}$ cellulose filter (Minisart®NML, Sartorius, Göttingen, Germany). Two hundred $\mu \mathrm{l}$ soil suspension (using wide mouth tips to avoid clogging) or filtrate were transferred into a 
96-well microtiter plate (polystyrene, Greiner Bio-one GmbH, Frickenhausen, Germany) containing 40 $\mu 1$ MES buffer (4-Morpholine-ethanesulfonic acid monohydrate, Sigma 69892, pH 5.2). When working with soil suspensions, MES buffer contained soil specific EDTA additions (see supplementary material) to reduce the soil P-sorption capacity and to increase recovery of enzymatically released orthophosphate. In accordance with each subset, model compound solution $(20 \mu \mathrm{l})$ and/or substrate specific enzyme solutions $(20 \mu \mathrm{l}$ non-phytase phosphomonoesterase, $40 \mu \mathrm{l}$ phytase, $20 \mu \mathrm{l}$ phosphomonoesterase combined with $20 \mu \mathrm{l}$ phosphodiesterase) were subsequently added. Since the phosphodiesterase hydrolyses only one of the two ester bonds in phosphodiesters, it was combined with the non-phytase phosphomonoesterase to ensure complete hydrolysis of all phosphodiesters. The following controls were included: stability of all model compounds against autohydrolysis was assessed by incubating 20 $\mu 1$ of model compound solution in buffered solution, and catalytic activity of added enzymes was assessed by incubating 20 or $40 \mu \mathrm{l}$ of the respective enzyme solution with $20 \mu \mathrm{l}$ of the respective model compound solution in a buffered solution only. Between four and eight analytical replicates (wells) were made for each subset. After addition of buffer, suspension or filtrate, model compounds, and enzymes, all wells were filled with water to $300 \mu \mathrm{l}$ final volume per well. Thereafter, plates were sealed with selfadhesive film (BRAND nr. 781390) and incubated for $24 \mathrm{~h}$ at $37^{\circ} \mathrm{C}$ by horizontal shaking at $400 \mathrm{rpm}$ $\left(\right.$ VorTemp ${ }^{\mathrm{TM}}$ 56). After incubation, microtiter plates containing soil suspensions were centrifuged at $2190 \mathrm{~g}$ before P quantification. All solutions used were prepared with autoclaved deionized water to guarantee sterility.

We realise that a limitation of our study was that all soil suspensions and filtrates were incubated at a constant $\mathrm{pH}$ of 5.2, which may not be the optimal $\mathrm{pH}$ for all soil derived phosphatases to hydrolyse the added organic $\mathrm{P}$ substrate. However, we think this factor was negligible, considering both the broad range of $\mathrm{pH}$ values under which most described phosphatases are active, and the favourable conditions (temperature, shaking, time) provided for their performance. Additionally, we realize that the addition of ETDA may not only affect the release of MRP into soil solution (see supplementary material) but also the release of MUP compounds. We are not aware of any study testing for this process. However, the only artefact that potentially could be created is a higher proportion of specific MUP compounds in soil:water filtrates what were previously sorbed on the soil solid phase and would be detected in soil:water suspensions.

\subsection{Determination of $P$ concentrations}

Concentrations of orthophosphate were determined colorimetrically using malachite green (Ohno and Zibilske, 1991) and are given as molybdate-reactive P (MRP), due to the well-known limitations with colorimetric determination of orthophosphate (Worsfold et al., 2005). Organic P was determined as the difference between total P and MRP. Organic P is referred to here as molybdate-unreactive P (MUP) since not only organic $\mathrm{P}$ but also polyphosphates (condensed inorganic phosphates), orthophosphate 
sorbed onto colloids or organic matter, and phosphate minerals are molybdate-unreactive (Sinaj et al., 1998; Gerke, 2010).

For MRP quantification from samples in microtiter plates, $30 \mu \mathrm{l}$ (for soil suspensions) or $200 \mu \mathrm{l}$ (for soil filtrates) of supernatant were transferred to another microtiter plate and $170 \mu 1$ of water were added to the samples from soil suspensions. Samples were then mixed with $50 \mu 1$ of each of the two malachite green reagents and absorbance was read at $620 \mathrm{~nm}$ in a plate reader (EL 800, Biotek) after one hour. For all other MRP determinations, $1 \mathrm{~cm}$ cuvettes and sample aliquots between 0.25 and $1 \mathrm{ml}$ were used. Water was added to reach a final volume of $2 \mathrm{ml}$ before $0.4 \mathrm{ml}$ of each malachite green reagent was added. Samples were analysed at $610 \mathrm{~nm}$ (UV-1800 Shimadzu Spectrometer) after one hour.

Due to low sample volume per well, total P could not be determined directly in the supernatant of the microtiter plates. Therefore, buffered soil suspensions or filtrates without addition of enzymes were incubated simultaneously with microtiter plates under 50 times up-scaled conditions. To this end, $10 \mathrm{ml}$ of suspension or filtrate were mixed with $2 \mathrm{ml}$ MES buffer ( $\mathrm{pH} 5.2$, final molarity 0.2 , containing soil specific EDTA additions for soil suspensions, see supplementary material) and $3 \mathrm{ml} \mathrm{H}_{2} \mathrm{O}$ in $50 \mathrm{ml}$ polypropylene conical centrifuge tubes. Extracts were incubated and gently shaken for $24 \mathrm{~h}$ at $37^{\circ} \mathrm{C}$. Soil suspensions were centrifuged (2190 g). Concentrations of MRP and total P were determined in the soil suspension supernatant or soil filtrate.

Total P concentrations of soil suspensions, soil filtrates and organic $\mathrm{P}$ model compounds were determined by digestion of $0.2-2 \mathrm{ml}$ sample aliquots with $2 \mathrm{ml}$ digestion mix $(6 \mathrm{~g}$ ammonium persulphate in $100 \mathrm{ml} 0.9 \mathrm{M} \mathrm{H}_{2} \mathrm{SO}_{4}$ ) in an autoclave, followed by colorimetric MRP determination. In filtrates, the MRP concentrations detected in plates and in the up-scaled experiment correlated well with each other (supplementary material, Figure S2). In soil suspensions, however, the up-scaling did not always produce MRP concentrations similar to those in microtiter plates (supplementary material, Figure S3). Additionally, in some soils we observed different concentrations of soil suspension total P, depending on whether the centrifuge tube used for upscaling was upright or horizontal while shaking. No clear trend for higher or lower MRP concentrations related to shaking position was observed. Consequently, both shaking positions were maintained. For data analysis, those samples were selected which had the closest MRP compared to MRP detected in microtiter plates (mean deviation from upscaling from MRP in microtiter plate $=13 \% \pm 33 \%$ standard deviation). For filtrates, MRP and total P were determined at two time points; first at time point zero, i.e., after $16 \mathrm{~h}$ shaking and filtering of the soil suspension $\left(\mathrm{MRP}_{\mathrm{t} 0}\right.$ and Total $\left.\mathrm{P}_{\mathrm{t} 0}\right)$; second, after $24 \mathrm{~h}$ of incubation $\left(\mathrm{MRP}_{\mathrm{t} 24}\right.$ and Total $\left.\mathrm{P}_{\mathrm{t} 24}\right)$. MUP in filtrates was calculated only after $24 \mathrm{~h}$ of incubation $\left(\mathrm{MUP}_{\mathrm{t} 24}\right)$ by difference between Total $\mathrm{P}_{\mathrm{t} 24}$ and $\mathrm{MRP}_{\mathrm{t} 24}$. 


\subsection{Calculations and statistical analyses}

Availability of active soil enzymes was assessed by determining the fraction of total $\mathrm{P}$ in model compounds that was released as the enzymatic hydrolysis product orthophosphate (MRP). To make this determination, the MRP released from buffered sediments or filtrates and from model compounds was corrected for background MRP in filtrate or suspension and background MRP in model compounds. Degree of model compound hydrolysis in suspensions or filtrates by indigenous phosphatases was determined as follows:

Hydrolysis of model compound by in situ phosphatases (\%)

$$
=\frac{\left(\begin{array}{c}
\text { MRP in suspenision or filtrate incubated with model compound } \\
- \text { MRP in model compound } \\
- \text { background MRP in suspension or filtrate }
\end{array}\right)}{\text { Total P in model compound }}
$$

Similarly, degree of model compound hydrolysis in suspensions or filtrates by both indigenous and added substrate specific phosphatases was determined as follows:

Hydrolysis of model compund by in situ and added phosphatases (\%)

$$
=\frac{\left(\begin{array}{c}
M R P \text { in suspenision or filtrate incubated with model compound } \\
\text { and substrate specific phosphatases } \\
-M R P \text { in model compound } \\
-M R P \text { in enzymes }
\end{array}\right.}{\text { Total } P \text { in model compound }}
$$

(2)

Available substrate of specific organic $\mathrm{P}$ compounds in a given sample (soil suspension or soil filtrate) by addition of substrate specific enzymes was calculated as follows:

Organic $P$ substrate class in sample

$$
\begin{aligned}
& \text { = MRP in sample incubated with substrate specific phosphatses } \\
& \text { - MRP in added substrate specific phosphatase enzymes } \\
& \text { - background MRP in suspension or filtrate }
\end{aligned}
$$

In soil suspensions, the incomplete recovery of MRP as hydrolysis product (as determined by an orthophosphate spike) ranged from $28-73 \%$ recovery and this was additionally corrected for (see supplementary material, Figure S1).

Four organic P substrate classes were quantified: 
i. $\quad$ Monoester-like P: MUP hydrolysed by acid non-phytase phosphomonoesterase

ii. Diester-like P: MUP hydrolysed by phosphodiesterase in combination with acid non-phytase phosphomonoesterase minus monoester-like $\mathrm{P}$

iii. $\quad$ Phytate-like P: MUP hydrolysed by phytase minus monoester-like P (since the phytase used also hydrolysed non-phytate phosphomonoesters)

iv. Enzyme-stable P: MUP not hydrolysed by any of the enzyme treatments.

Since the calculations to determine different organic $\mathrm{P}$ classes were based on the subtraction of $\mathrm{P}$ concentrations in enzyme-treated and untreated extracts and background concentrations in enzyme solutions, negative values were sometimes obtained. If three or fewer of the eight plate wells containing the same sample were negative, those values were omitted. When more than three out of eight wells containing the same sample were negative, the enzyme hydrolysable MUP class in the particular extract was set to zero. Even after microtiter plates incubated with soil suspensions were centrifuged, particles were occasionally transferred to the microtiter plate for colorimetry, impeding the reliable determination of MRP concentrations by colorimetry (interference with particles). Such individual pipetting replicates were removed as well, mostly for Cambisol (2).

Increases in MRP by enzymatic hydrolysis have to be quantified against soil specific MRP background concentrations in soil suspensions and filtrates. For that reasons, soil-specific limits of detection (DL) and limits of quantification (QL) for enzyme-labile MUP classes (monoester-like P, diester-like P and phytate-like P) were determined for soil suspensions and filtrates following the recommendations of MacDougall and Crummett (1980)

$$
D L=\operatorname{mean} B+3 \times \operatorname{stdevB}
$$

and

$$
Q L=\operatorname{mean} B+10 \times \operatorname{stdev} B
$$

where mean $B$ and $\operatorname{stdev} B$ are the average and standard deviation of a blank. Soil MRP concentrations from eight analytical replicates per microtiter plate were chosen as blanks in this case, since enzymelabile $\mathrm{P}$ is quantified as the difference in MRP between samples amended and not amended with substrate specific enzymes. The DL and QL are shown as the mean of two or three replicates, and are reported without the mean background MRP concentration for each soil individually.

A Kruskal-Wallis test was performed to test for significant differences in the degree of hydrolysis of model compounds either by indigenous enzymes alone or with added substrate specific enzymes. Statistical analyses and figures were made using the software R (R Development Core Team, 2010). 


\section{Results}

\subsection{Substrate availability}

Availability of specific organic $P$ substrates in soil suspensions and soil filtrates was estimated by adding substrate specific phosphatases to soil suspensions and soil filtrates. We decreased soil P sorption and increased MRP recovery by soil-specific EDTA additions to soil suspensions (supplementary material, Figure S1). In suspensions, the characterisation of different MUP classes was possible for only three of the ten analysed soils; Luvisol (1), Cambisol (3), and Ferralsol (1), and was not dependent on MUP concentration, which ranged from 0.2 to $27.8 \mathrm{mg} \mathrm{kg}^{-1}$ in the ten soils (Table 2). Phytate-like $\mathrm{P}$ was found only in Cambisol (3), while monoester-like $\mathrm{P}$ and diester-like $\mathrm{P}$ were detected in all three soils, but in lower concentrations. In Luvisol (1) and Cambisol (3), the sum of enzyme-labile MUP was higher than total MUP in the sample, owing to difficulties in finding an ideal up-scaling condition for total $\mathrm{P}$ determination (Section 2.3, supplementary material, Figure S3). The calculated DLs were relatively high for all soil suspensions $\left(0.3-8.8 \mathrm{mg} \mathrm{kg}^{-1}\right.$ soil $)$, due to the increased background MRP concentrations by soil-specific EDTA additions and some variability in quantified MRP. In filtrates (Table 3), the quantification of organic $\mathrm{P}$ substrate was limited due to low $\mathrm{MUP}_{\mathrm{t} 24}$ concentrations, ranging from 0.1 $6.7 \mathrm{mg} \mathrm{kg}^{-1}$. Phytate-like $\mathrm{P}$ was the most prominent enzyme-labile MUP class, detected in eight of ten soils $\left(0.1-0.6 \mathrm{mg} \mathrm{kg}^{-1}\right)$. Monoester-like $\mathrm{P}$ and diester-like $\mathrm{P}$ were found in concentrations lower than $0.1 \mathrm{mg} \mathrm{P} \mathrm{kg}{ }^{-1}$, except for Cambisol (2) with $2.6 \mathrm{mg} \mathrm{kg}^{-1}$ monoester-like P and Cambisol (3) with $0.3 \mathrm{mg}$ $\mathrm{P} \mathrm{kg}^{-1}$ diester-like P. In several cases concentrations were below the QL or even below the DL (Table 3). Enzyme-stable $P$ was the dominant MUP fraction in eight of the ten analysed soils. In summary, the mean availability of MUP substrate in soil filtrates could be ranked as enzyme-stable P >> phytate-like $\mathrm{P}>$ diester-like $\mathrm{P} \geq$ monoester-like $\mathrm{P}$.

\subsection{Enzyme availability}

Availability of specific soil derived phosphatases in soil suspensions and filtrates was determined by assessing the degree of model compound hydrolysis after addition to soil suspensions and filtrates (Figure 2). High indigenous activities of non-phytase phosphomonoesterases resulted in the hydrolysis of the added non-phytate phosphomonoester substrate (GP) in all soil suspensions (5-63\%, mean 40\%) and in three soil filtrates (56-87\%, mean of all ten soils: $29 \%$ ), indicating high enzyme availability. In contrast, soil-derived phytases and phosphodiesterases showed little hydrolytic activity in response to the added model compounds Ins6P and DNA in both suspensions and filtrates (mean 6\%), indicating low availability of both enzymes. This applied also to the seven soil filtrates in which little hydrolysis of added GP was observed.

When the model compounds were added in combination with the respective phosphatase enzymes, full hydrolysis of all model compounds was observed in filtrates. Thus, unfavourable conditions for soil- 
derived enzymes can be excluded as an explanation for the absence of added model compound hydrolysis. In soil suspensions, the percentage of model compound hydrolysis after addition of the respective enzyme(s) ranged from 19 to $100 \%$ (mean $54 \%$ ). An apparently incomplete hydrolysis after adding an excess of enzyme(s) with the substrate can be explained by the partial recovery of the hydrolysis product MRP due to its rapid sorption onto the soil solid phase. Importantly, no additional hydrolysis of GP was observed in soil suspensions after addition of the respective enzyme acid phosphomonoesterase (Kruskal-Wallis test, Figure 2a), suggesting that all the added substrate (GP) had already been fully hydrolysed by soil derived non-phytase phosphomonoesterases.

In the absence of soil suspension or soil filtrate, all model compounds remained stable and were always completely hydrolysed when incubated with the respective enzyme(s) in buffered solution (data not shown), indicating sterile preparation and ideal incubation conditions.

\section{Discussion}

Limitations to organic P hydrolysis depended on sample type. In soil:water filtrates, hydrolysis of all organic P classes was enzyme-limited, in accordance with our second hypothesis. In soil:water suspensions, however, we consistently demonstrated that the hydrolysis of non-phytate phosphomonoesters was driven by comparatively low substrate availability in combination with high enzyme availability. Thus, the hydrolysis of non-phytate phosphomonoesters in suspensions was determined to be substrate limited. In contrast, the availability of phosphodiesters and phytate in soil:water suspensions was similar to or higher than that of non-phytate monoesters, with little availability of the respective indigenous phosphatases. The hydrolysis of both phosphodiesters and phytate in suspensions was therefore enzyme limited. With respect to phosphodiesters, this was in contrast to our first hypothesis.

Our approach to determine substrate limitation or enzyme limitation for specific organic $\mathrm{P}$ compounds was applicable in the ten tested soils with strongly differing properties and origins, confirming our third hypothesis. Due to the differences in findings in soil:water filtrates and soil:water suspensions, we first discuss the findings in filtrates, then discuss substrate-limitation vs. enzyme-limitation in soil suspensions.

\subsection{Enzyme-limited hydrolysis of all organic $P$ classes in soil filtrates}

In soil filtrates, little hydrolysis of any of the added organic P substrates was found in the absence of added enzymes, except for GP in three filtrates (Figure 2b). This is in agreement with other studies in which only a small fraction of soil phosphatase activity was found in soil water filtrates compared to soil suspensions (Kandeler, 1990; George et al., 2005a). Greater hydrolysis of added GP occurred in filtrates of grassland soils (8-87\%; mean 51\%) than of arable soils (4-10\%; mean 7\%). A similar landuse effect was observed in soils from both the boreal and the temperate zones (Wallenius et al., 2011; 
Lebrun et al., 2012). It is likely that a small fraction of enzymes was desorbed from the soil solid phase during preparation of the soil suspensions and transferred to the filtrates. Interestingly, we found a positive linear correlation between the soils' silt content and the percentage of non-phytate phosphomonoester (GP) hydrolysed by soil-derived enzymes in soil filtrates (Pearson's $r=0.71, p<$ 0.05). Previous studies have also reported the accumulation of alkaline non-phytase phosphomonoesterases especially in the soil silt $(2-63 \mu \mathrm{m})$ fraction (Kandeler et al., 1999; Kandeler et al., 2000).

\subsection{Substrate-limited hydrolysis of non-phytate phosphomonoesters in soil suspensions}

The substrate limitation of non-phytate phosphomonoester hydrolysis identified in soil suspensions (Figure 2a) could have several underlying explanations, including different rates of production of organic P substrates and enzymes by soil biota and plants, different stabilisation mechanisms in soil, and differences in enzymatic activity, as synthesized in Figure 3.

Non-phytate phosphomonoesters such as sugar phosphates or cleavage products from phosphodiesters (e.g., nucleotides) are released into soil by both plants and microorganisms. We are not aware of available data on release rates of specific non-phytate phosphomonoesters into soil. However, phosphomonoesters (including both non-phytate and phytate monoesters) comprise only between 10 and $30 \%$ of organic P in different microorganisms (Magid et al., 1996; Bünemann et al., 2008), which after microbial death are likely released into soil. Similarly, studies using ${ }^{31} \mathrm{P}$ NMR spectroscopy for organic P speciation have indicated relatively low concentrations of non-phytate phosphomonoesters in different crops (Noack et al., 2012; Noack et al., 2014). Taken together, these results suggest relatively low inputs of non-phytase phosphomonoesters into soil compared to other organic P compounds (Section 4.3). Stabilisation of non-phytate phosphomonoesters on the soil solid phase, controlled by the negative charge of the orthophosphate moiety enabling it to be adsorbed onto soil iron and aluminium hydroxyl-oxides, is similar to that of phosphodiesters (Celi and Barberis, 2005). As a result of comparatively low production and intermediate stabilisation, non-phytate phosphomonoesters may be available for enzymatic hydrolysis in soil suspensions only at low levels.

Phosphatases are actively excreted by plants, and their production is stimulated by low available $\mathrm{P}$ concentrations in soil. Non-phytase phosphomonoesterases are the main enzyme class excreted by plants in many cases (Li et al., 1997; Hayes et al., 1999; Richardson et al., 2001). Microorganisms can also react to low $\mathrm{P}$ availability by active expression of phosphatases, and different bacterial phyla such as Acidobacteria, Actinobacteria, Cyanobacteria, Firmicutes, Planctomycetes, and Proteobacteria have been shown to harbour genes for expression of, e.g., PhoD and PhoX phosphatases (Ragot et al., 2016). Bacteria harbouring phosphatase genes are widespread in terrestrial ecosystems (Tan et al., 2013; Ragot et al., 2016), and microorganisms appear to produce non-phytase phosphomonoesterases at higher rates than other phosphatases (Renella et al., 2007). Phosphatases differ in their maximum enzyme activities 
$\left(\mathrm{V}_{\max }\right)$, i.e., the rate of enzymatic substrate degradation under full substrate availability derived from Michaelis-Menten kinetics (Johnson and Goody, 2011). In a literature review, Hui et al. (2013) determined an average $\mathrm{V}_{\max }$ value of $5.32 \mu \mathrm{mol} p \mathrm{NPg}^{-1} \mathrm{~h}^{-1}$ for acid and $3.67 \mu \mathrm{mol} p \mathrm{NPg}^{-1} \mathrm{~h}^{-1}$ for alkaline non-phytase phosphomonoesterases. These are substantially higher than $V_{\max }$ values of phosphodiestereases reported in several individual studies (Browman and Tabatabai, 1978; Sparling et al., 1986; Margesin and Schinner, 1994; Turner and Haygarth, 2005) or activities reported for phytases in soil (Berry et al., 2011). In addition, non-phytase phosphomonoesterases appear to be more efficient in hydrolysing organic P compounds than phosphodiesterases (Allison et al., 2007) or phytases (Yadav and Tarafdar, 2003). The persistence of an enzyme (i.e., its resistance to degradation) further influences overall enzymatic activity in soil. Non-phytase phosphomonoesterases persist longer in soil than phosphodiesterases and phytases (George et al., 2007; Renella et al., 2007), likely due to the rather high resistance to degradation by soil proteolytic enzymes (Schimel et al., 2017) and by stabilisation on soil organo-mineral surfaces (Burns et al., 2013). We do not have data on the kinetics of phosphatase activities in our soils. Nevertheless, activities of non-phytate phosphomonoesterases in soil suspensions were much higher than activities of phytases and phosphodiesterases (Figure 2a; $p \leq 0.01$, KruskalWallis test), suggesting substrate limitation of non-phytate phosphomonoester hydrolysis in soil suspensions.

Using substrate-specific enzymes to determine non-phytase phosphomonoester substrate classes might lead to their underestimation, given the high availability of non-phytase phosphomonoesterases in the samples. The observed increase from $\mathrm{MRP}_{\mathrm{t} 0}$ to $\mathrm{MRP}_{\mathrm{t} 24}$ (Table 3) in the untreated samples suggests hydrolysis of MUP by soil-derived phosphomonoesterases during incubation. Similar observations have been made for soil solutions (Shand and Smith, 1997) and pre-concentrated soil leachates (Espinosa et al., 1999). Alternative methods such as mass spectroscopy (Cooper et al., 2005) should thus be considered for estimation of available organic $\mathrm{P}$ substrate in future studies.

\subsection{Enzyme-limited hydrolysis of phytate and phosphodiesters in soil suspensions}

Phytate is a major P storage compound in plants (Raboy, 1997) and thus enters soil together with phosphodiesters (as DNA, RNA or phospholipids) at relatively high rates (Magid et al., 1996; Noack et al., 2012). Given its higher charge density than other organic P compounds, phytate is strongly stabilised onto the soil solid phase (Ognalaga et al., 1994; Turner et al., 2002; Celi and Barberis, 2005), which should decrease its availability for enzymatic hydrolysis compared to other organic P compounds such as phosphodiesters.

There is limited information on the production of phytases and phosphodiesterases by soil biota and plants. For example, two barley genotypes grown under sterile conditions had approximately 6 times lower root extracellular phosphodiesterase and phytase than non-phytase phosphomonoesterase activity (Asmar, 1997; Asmar and Gissel-Nielsen, 1997). Also for other plants, phytase activity was substantially 
lower than activity of non-phytase phosphomonoesterases (Hayes et al., 1999; Richardson et al., 2000; Viveros et al., 2000; Richardson et al., 2001; Louw-Gaume et al., 2010), and several studies have reported that a significant release of phytase from plant roots was achieved only by genetic manipulation (Richardson et al., 2001; Zimmermann et al., 2003; George et al., 2005b; Xiao et al., 2005). While the activity of non-phytase phosphomonoesterase in roots of wetland plants was similar to that of phosphodiesterase (Rejmánková et al., 2011), it should be noted that the activity of phosphodiesterases can be easily overestimated by the presence of phosphomonoesterases when using artificial substrate for enzyme activity determinations (Sirová et al., 2013). With a few exceptions, microbes produce only intracellular phytases (Singh et al., 2018). Nevertheless, addition of phytase producing bacteria to model systems, i.e., plants grown on agar with an organic $\mathrm{P}$ source, was shown to strongly increase $\mathrm{P}$ availability from phytate for plants (Richardson et al., 2000). Taken together, these examples indicate that the active or passive release of phosphodiesterases and phytases into soil from both plants and microorganisms is quantitatively much lower than that of non-phytase phosphomonoesterases.

The activities of phytases as well as their resistance to degradation appear to depend on their origins as well as on physical soil properties (George et al., 2007). Phytases get quickly adsorbed onto the soil solid phase after release into soil solution, where their activity is somewhat sustained (George et al., 2005a; Giaveno et al., 2010). It is not known if similar factors determine the stability of phosphodiesterases, and if their activity can be sustained to some degree after stabilization on the soil solid phase. The slightly higher hydrolysis of model compound DNA than of phytate in soil suspensions (Figure 2) suggests that phosphodiesterases sustain slightly higher activity than phytases do after stabilization in soil.

\subsection{Implications for soil organic $P$ accumulation and mineralization}

In a previous study (Jarosch et al., 2015), we applied enzyme addition assays to alkaline soil extracts $(0.25 \mathrm{M}$ sodium hydroxide $(\mathrm{NaOH})$ and $0.05 \mathrm{M}$ ethylenediaminetetraacetic acid (EDTA)) to extract and characterise the bulk organic P in the same soils as used in the present study. Enzyme addition assays suggested that non-phytate phosphomonoesters comprised between 15 and 54\% (mean 35\%) of alkalineextractable organic P, which was less than phytate-like P (32 to $74 \%$, mean $54 \%$ ) but more than phosphodiester-like P (0 to 15\%, mean 11\%) (Jarosch et al., 2015). However, we did not find a significant correlation between organic $\mathrm{P}$ classes in $\mathrm{NaOH}$-EDTA extracts and in soil:water filtrates or suspensions (Table 2, Table 3), respectively (supplementary material, Figure S4). This lack of a relationship may be explained by the fact that organic $\mathrm{P}$ classes in those regions of the soil relevant for immediate biological transformations such as enzymatic hydrolysis or microbial immobilisation (as approximated by the soil extraction with water) are different from those found in bulk soil (as approximated by the soil extraction with $\mathrm{NaOH}$-EDTA). In particular, although significant amounts of non-phytate phosphomonoesters occur in bulk soil, their low occurrence in soil:water filtrates and 
suspensions is in accordance with a lack of accumulation in places where they are affected by the high availability of non-phytase phosphomonoesterases. We speculate that either physical separation between substrate and enzyme (e.g. by inclusion into macromolecules or soil aggregates) or environmental conditions unfavourable for enzymatic hydrolysis (e.g., $\mathrm{pH}$, temperature, drought, strong sorption onto mineral surfaces) are the main drivers for the accumulation of non-phytate phosphomonoesters in soil.

Phytate accumulation in soil was previously explained by strong sorption and thus stabilisation on the soil solid phase (Ognalaga et al., 1994). The observed enzyme limitation for the hydrolysis of phytate in soil suspensions may additionally contribute to the stabilisation and accumulation of phytate in soil. In hydrolysis of phosphodiesters, we observed an enzyme limitation in soil:water suspensions (Figure 2). Increased concentrations of phosphodiesters were observed in forest soils with low P-availability and a high phosphomonoesterase to phosphodiesterase activity ratio (Lang et al., 2017). Given a large production of phosphodiesters in soil (Figure 3), greater accumulation of these compounds could be expected, while in the alkaline-extractable organic $\mathrm{P}$ analysis of the soils used in this study phosphodiesters were the least abundant enzyme-labile organic P class (Jarosch et al., 2015). Again, we assume that this mismatch is explained by differences in extractability, and that characterisation of total organic $\mathrm{P}$ does not inform which organic $\mathrm{P}$ classes are available in soil $\mathrm{P}$ fractions such as soil:water suspensions, which are likely more relevant for biological transformations. Additionally, quantification of phosphodiesters in soil using ${ }^{31} \mathrm{P}$ NMR spectroscopy still has some uncertainties due to phosphodiester degradation during soil extraction and/or subsequent analysis (Makarov et al., 2002; Jarosch et al., 2015).

Turner (2008) suggested that plant species could specialise in the mobilisation of particular organic $\mathrm{P}$ compounds in soil to satisfy their P demand. In view of our findings, such a specialisation would be particularly useful to mobilise phytate and phosphodiesters, given the enzyme-limited hydrolysis of these organic $\mathrm{P}$ substrates in soil. Interestingly, the production of non-phytase phosphomonoesterases shows distinct spatial patterns in the rhizosphere, with higher activities of root and microbial acid nonphytase phosphomonoesterases close to roots, and more homogeneous distribution in soil of solely microbial-derived alkaline non-phytase phosphomonoesterase (Spohn and Kuzyakov, 2013). Such spatial segregation may hold also true for other phosphatases.

\section{Conclusion}

Based on ten soils with different properties, origin and land use, the enzymatic hydrolysis of non-phytate phosphomonoesters such as sugar phosphates or nucleotides appears to be limited by availability of the specific organic P substrate and not by availability of the respective enzymes. In contrast, the hydrolysis of phytate and phosphodiesters appears to be limited by availability of enzymes. This implies that an active excretion of phytases and phosphodiesterases by biota is required to access these compounds as 
P sources. These observed differences can be explained by higher production rates of non-phytase phosphomonoesterases (both constitutive and induced) by soil biota and by stronger stabilisation of nonphytase phosphomonoesterases compared to other phosphatases in soil. The preferential accumulation of phytate over other organic P compounds in soil may be due not only to its strong stabilisation on the soil solid phase, but also due to the lack of phytase. Our findings also have implications for the characterisation of organic $\mathrm{P}$ in soil filtrates or soil suspensions using the enzyme addition approach, as indigenous non-phytase phosphomonoesterase activity may lead to an underestimation of monoesterlike P. Besides, since the characterization of MUP in soil suspensions using the enzyme addition approach was successful only in three soils, partly due to high detection limits, further refinement of the method is required.

\section{Acknowledgements}

We thank everyone who kindly provided soil samples for this study, namely J. Mayer, Agroscope (Luvisol (1)), K. Annaheim (Cambisol (2)), O. Huguenin-Elie, Agroscope (Cambisol (3)), R. Flisch, Agroscope (Cambisol (4)), B. Eichler-Löbermann (Luvisol (2)), D. Hegglin (Ferralsol (1)), F. Lompo and M. Sedogo, INERA (Lixisol (1)), L. Randriamanantsoa (Ferralsol (2)) and R. Simpson, CSIRO (Alfisol (1)). We thank Arne Korsbak from Novozyme (DSM Nutritional Products) for the supply with Ronozyme NP (M). This study was funded by the Swiss National Science Foundation (Project number 31003A_140900) and the German Research Foundation (DFG, KA1590/12-1 and KA1590/12-2). We acknowledge the critical and helpful comments of two anonymous reviewers. 


\section{References}

Allison, S.D., Vitousek, P.M., 2005. Responses of extracellular enzymes to simple and complex nutrient inputs. Soil Biology and Biochemistry 37, 937-944.

Allison, V., Condron, L., Peltzer, D., Richardson, S., Turner, B., 2007. Changes in enzyme activities and soil microbial community composition along carbon and nutrient gradients at the Franz Josef chronosequence, New Zealand. Soil Biology and Biochemistry 39, 1770-1781.

Annaheim, K.E., Rufener, C.B., Frossard, E., Bünemann, E.K., 2013. Hydrolysis of organic phosphorus in soil water suspensions after addition of phosphatase enzymes. Biology and Fertility of Soils 49, 1203-1213.

Asmar, F., 1997. Variation in activity of root extracellular phytase between genotypes of barley. Plant and Soil 195, 61-64.

Asmar, F., Gissel-Nielsen, G., 1997. Extracellular phosphomono-and phosphodiesterase associated with and released by the roots of barley genotypes: a non-destructive method for the measurement of the extracellular enzymes of roots. Biology and Fertility of Soils 25, 117-122.

Berry, D.F., Walker, H.L., Harich, K., Shang, C., 2011. Assessing phytase activity in forested and agricultural soils using $\mathrm{TInsP}_{5}$ as a substrate analog. Soil Science Society of America Journal 75, 880-889.

Browman, M., Tabatabai, M., 1978. Phosphodiesterase activity of soils ${ }^{1}$. Soil Science Society of America Journal 42, 284-290.

Bünemann, E., Smernik, R.J., Doolette, A.L., Marschner, P., Stonor, R., Wakelin, S., McNeill, A., 2008. Forms of phosphorus in bacteria and fungi isolated from two Australian soils. Soil Biology and Biochemistry 40, 1908-1915.

Bünemann, E.K., 2008. Enzyme additions as a tool to assess the potential bioavailability of organically bound nutrients. Soil Biology and Biochemistry 40, 2116-2129.

Burns, R.G., DeForest, J.L., Marxsen, J., Sinsabaugh, R.L., Stromberger, M.E., Wallenstein, M.D., Weintraub, M.N., Zoppini, A., 2013. Soil enzymes in a changing environment: Current knowledge and future directions. Soil Biology and Biochemistry 58, 216-234.

Celi, L., Barberis, E., 2005. Abiotic stabilization of organic phosphorus in the environment, In: Turner, B.L., Frossard, E., Baldwin, D.S. (Eds.), Organic phosphorus in the environment. CABI Publishing, Wallingford, UK, pp. 113-132.

Cooper, W.T., Llewelyn, J.M., Bennett, G.L., Stenson, A.C., Salters, V.J., 2005. Organic phosphorus speciation in natural waters by mass spectrometry, In: Turner, B.L., Frossard, E., Baldwin, D.S. (Eds.), Organic phosphorus in the environment. CABI Publishing, Wallingford, UK, pp. 45-74.

Darch, T., Blackwell, M.S., Hawkins, J., Haygarth, P.M., Chadwick, D., 2014. A meta-analysis of organic and inorganic phosphorus in organic fertilizers, soils, and water: Implications for water quality. Critical Reviews in Environmental Science and Technology 44, 2172-2202.

Datta, R., Anand, S., Moulick, A., Baraniya, D., Pathan, S.I., Rejsek, K., Vranova, V., Sharma, M., Sharma, D., Kelkar, A., 2017. How enzymes are adsorbed on soil solid phase and factors limiting its activity: A Review. International agrophysics 31, 287-302.

del Pozo, J.C., Allona, I., Rubio, V., Leyva, A., de La Peña, A., Aragoncillo, C., Paz-Ares, J., 1999. A type 5 acid phosphatase gene from Arabidopsis thaliana is induced by phosphate starvation and by some other types of phosphate mobilising/oxidative stress conditions. The Plant Journal 19, 579-589.

Dick, W., Tabatabai, M., 1984. Kinetic parameters of phosphatases in soils and organic waste materials. Soil Science 137, 7-15.

Doolette, A.L., Smernik, R.J., Dougherty, W.J., 2010. Rapid decomposition of phytate applied to a calcareous soil demonstrated by a solution ${ }^{31} \mathrm{P}$ NMR study. European Journal of Soil Science 61, 563-575.

Eivazi, F., Tabatabai, M., 1977. Phosphatases in soils. Soil Biology and Biochemistry 9, 167-172. 
Espinosa, M., Turner, B.L., Haygarth, P.M., 1999. Preconcentration and separation of trace phosphorus compounds in soil leachate. Journal of Environmental Quality 28, 1497-1504.

Fransson, A.M., Jones, D.L., 2007. Phosphatase activity does not limit the microbial use of low molecular weight organic-P substrates in soil. Soil Biology and Biochemistry 39, 1213-1217.

Freeman, C., Ostle, N., Fenner, N., Kang, H., 2004. A regulatory role for phenol oxidase during decomposition in peatlands. Soil Biology and Biochemistry 36, 1663-1667.

George, T.S., Richardson, A.E., Simpson, R.J., 2005a. Behaviour of plant-derived extracellular phytase upon addition to soil. Soil Biology and Biochemistry 37, 977-988.

George, T.S., Simpson, R.J., Gregory, P.J., Richardson, A.E., 2007. Differential interaction of Aspergillus niger and Peniophora lycii phytases with soil particles affects the hydrolysis of inositol phosphates. Soil Biology and Biochemistry 39, 793-803.

George, T.S., Simpson, R.J., Hadobas, P.A., Richardson, A.E., 2005b. Expression of a fungal phytase gene in Nicotiana tabacum improves phosphorus nutrition of plants grown in amended soils. Plant Biotechnology Journal 3, 129-140.

Gerke, J., 2010. Humic (organic matter)-Al(Fe)-phosphate complexes: An underestimated phosphate form in soils and source of plant-available phosphate. Soil Science 175, 417-425.

Giaveno, C., Celi, L., Richardson, A.E., Simpson, R.J., Barberis, E., 2010. Interaction of phytases with minerals and availability of substrate affect the hydrolysis of inositol phosphates. Soil Biology and Biochemistry 42, 491-498.

Harrison, A.F., 1987. Soil organic phosphorus: a review of world literature. CAB International Wallingford.

Hayes, J.E., Richardson, A.E., Simpson, R.J., 1999. Phytase and acid phosphatase activities in extracts from roots of temperate pasture grass and legume seedlings. Functional Plant Biology 26, 801809.

Hui, D., Mayes, M.A., Wang, G., 2013. Kinetic parameters of phosphatase: A quantitative synthesis. Soil Biology and Biochemistry 65, 105-113.

Jarosch, K.A., Doolette, A.L., Smernik, R.J., Tamburini, F., Frossard, E., Bünemann, E.K., 2015. Characterisation of soil organic phosphorus in $\mathrm{NaOH}$-EDTA extracts: A comparison of ${ }^{31} \mathrm{P}$ NMR spectroscopy and enzyme addition assays. Soil Biology and Biochemistry 91, 298-309.

Johnson, K.A., Goody, R.S., 2011. The original Michaelis constant: translation of the 1913 MichaelisMenten paper. Biochemistry 50, 8264-8269.

Kandeler, E., 1990. Characterization of free and adsorbed phosphatases in soils. Biology and Fertility of Soils 9, 199-202.

Kandeler, E., Palli, S., Stemmer, M., Gerzabek, M.H., 1999. Tillage changes microbial biomass and enzyme activities in particle-size fractions of a Haplic Chernozem. Soil Biology and Biochemistry 31, 1253-1264.

Kandeler, E., Tscherko, D., Bruce, K., Stemmer, M., Hobbs, P.J., Bardgett, R.D., Amelung, W., 2000. Structure and function of the soil microbial community in microhabitats of a heavy metal polluted soil. Biology and Fertility of Soils 32, 390-400.

Lang, F., Krüger, J., Amelung, W., Willbold, S., Frossard, E., Bünemann, E., Bauhus, J., Nitschke, R., Kandeler, E., Marhan, S., 2017. Soil phosphorus supply controls P nutrition strategies of beech forest ecosystems in Central Europe. Biogeochemistry, 1-25.

Lebrun, J.D., Trinsoutrot-Gattin, I., Vinceslas-Akpa, M., Bailleul, C., Brault, A., Mougin, C., Laval, K., 2012. Assessing impacts of copper on soil enzyme activities in regard to their natural spatiotemporal variation under long-term different land uses. Soil Biology and Biochemistry 49, 150-156.

Li, M., Osaki, M., Rao, I.M., Tadano, T., 1997. Secretion of phytase from the roots of several plant species under phosphorus-deficient conditions. Plant and Soil 195, 161-169. 
Louw-Gaume, A.E., Rao, I.M., Gaume, A.J., Frossard, E., 2010. A comparative study on plant growth and root plasticity responses of two Brachiaria forage grasses grown in nutrient solution at low and high phosphorus supply. Plant and Soil 328, 155-164.

MacDougall, D., Crummett, W.B., 1980. Guidelines for data acquisition and data quality evaluation in environmental chemistry. Analytical Chemistry 52, 2242-2249.

Macklon, A., Grayston, S., Shand, C., Sim, A., Sellars, S., Ord, B., 1997. Uptake and transport of phosphorus by Agrostis capillaris seedlings from rapidly hydrolysed organic sources extracted from ${ }^{32}$ P-labelled bacterial cultures. Plant and Soil 190, 163-167.

Magid, J., Tiessen, H., Condron, L., 1996. Dynamics of organic phosphorus in soils under natural and agricultural ecosystems. Humic substances in terrestrial ecosystems. Elsevier, Amsterdam, 429-466.

Makarov, M.I., Haumaier, L., Zech, W., 2002. Nature of soil organic phosphorus: an assessment of peak assignments in the diester region of P-31 NMR spectra. Soil Biology and Biochemistry 34, 14671477.

Margesin, R., Schinner, F., 1994. Phosphomonoesterase, phosphodiesterase, phosphotriesterase, and inorganic pyrophosphatase activities in forest soils in an alpine area: effect of pH on enzyme activity and extractability. Biology and Fertility of Soils 18, 320-326.

McLaren, T.I., Verel, R., Frossard, E., 2019. The structural composition of soil phosphomonoesters as determined by solution ${ }^{31} \mathrm{P}$ NMR spectroscopy and transverse relaxation (T2) experiments. Geoderma 345, 31-37.

Nannipieri, P., 1994. The potential use of soil enzymes as indicators of productivity, sustainability and pollution. Soil biota: management in sustainable farming systems, 238-244.

Nannipieri, P., Giagnoni, L., Landi, L., Renella, G., 2011. Role of phosphatase enzymes in soil, In: Bünemann, E.K., Oberson, A., Frossard, E. (Eds.), Phosphorus in Action: Biological Processes in Soil Phosphorus Cycling. Springer, Heidelberg, pp. 215-243.

Noack, S.R., McLaughlin, M.J., Smernik, R.J., McBeath, T.M., Armstrong, R.D., 2012. Crop residue phosphorus: speciation and potential bio-availability. Plant and Soil 359, 375-385.

Noack, S.R., Smernik, R.J., McBeath, T.M., Armstrong, R.D., McLaughlin, M.J., 2014. Assessing crop residue phosphorus speciation using chemical fractionation and solution 31P nuclear magnetic resonance spectroscopy. Talanta 126, 122-129.

Noll, L., Zhang, S., Zheng, Q., Hu, Y., Wanek, W., 2019. Wide-spread limitation of soil organic nitrogen transformations by substrate availability and not by extracellular enzyme content. Soil Biology and Biochemistry 133, 37-49.

Ognalaga, M., Frossard, E., Thomas, F., 1994. Glucose-1-phosphate and myo-inositol hexaphosphate adsorption mechanisms on goethite. Soil Science Society of America Journal 58, 332-337.

Ohno, T., Zibilske, L.M., 1991. Determination of low concentrations of phosphorus in soil extracts using malachite green. Soil Science Society of America Journal 55, 892-895.

R Development Core Team, 2010. R: A language and environment for statistical computing. $R$ Foundation for Statistical Computing, Vienna, Austria.

Raboy, V., 1997. Accumulation and Storage of Phosphate and Minerals, In: Larkins, B.A., Vasil, I.K. (Eds.), Cellular and Molecular Biology of Plant Seed Development. Springer Science+Business Media Dordrecht, Dordrecht, The Netherlands, pp. 441-477.

Ragot, S.A., Kertesz, M.A., Mészáros, É., Frossard, E., Bünemann, E.K., 2016. Soil phoD and phoX alkaline phosphatase gene diversity responds to multiple environmental factors. Fems Microbiology Ecology 93, fiw212.

Rejmánková, E., Sirová, D., Carlson, E., 2011. Patterns of activities of root phosphomonoesterase and phosphodiesterase in wetland plants as a function of macrophyte species and ambient phosphorus regime. New Phytologist 190, 968-976.

Renella, G., Szukics, U., Landi, L., Nannipieri, P., 2007. Quantitative assessment of hydrolase production and persistence in soil. Biology and Fertility of Soils 44, 321-329. 
Richardson, A., Hadobas, P., Hayes, J., 2000. Acid phosphomonoesterase and phytase activities of wheat (Triticum aestivum L.) roots and utilization of organic phosphorus substrates by seedlings grown in sterile culture. Plant, cell \& environment 23, 397-405.

Richardson, A.E., Hadobas, P.A., Hayes, J.E., 2001. Extracellular secretion of Aspergillus phytase from Arabidopsis roots enables plants to obtain phosphorus from phytate. The Plant Journal 25, 641-649.

Richardson, A.E., Hocking, P.J., Simpson, R.J., George, T.S., 2009. Plant mechanisms to optimise access to soil phosphorus. Crop and Pasture Science 60, 124-143.

Schimel, J., Becerra, C.A., Blankinship, J., 2017. Estimating decay dynamics for enzyme activities in soils from different ecosystems. Soil Biology and Biochemistry 114, 5-11.

Schmidt, M.W.I., Torn, M.S., Abiven, S., Dittmar, T., Guggenberger, G., Janssens, I.A., Kleber, M., KogelKnabner, I., Lehmann, J., Manning, D.A.C., Nannipieri, P., Rasse, D.P., Weiner, S., Trumbore, S.E., 2011. Persistence of soil organic matter as an ecosystem property. Nature 478, 49-56.

Shand, C.A., Smith, S., 1997. Enzymatic release of phosphate from model substrates and P compounds in soil solution from a peaty podzol. Biology and Fertility of Soils 24, 183-187.

Sinaj, S., Mächler, F., Frossard, E., Faïsse, C., Oberson, A., Morel, C., 1998. Interference of colloidal particles in the determination of orthophosphate concentrations in soil water extracts. Communications in Soil Science and Plant Analysis 29, 1091-1105.

Singh, N., Kuhar, S., Priya, K., Jaryal, R., Yadav, R., 2018. Phytase: The Feed Enzyme, an Overview, In: Gahlawat, S.K., Duhan, J.S., Salar, R.K., Siwach, P., Kumar, S., Kaur, P. (Eds.), Advances in Animal Biotechnology and its Applications. Springer, Singapore, pp. 269-327.

Sirová, D., Rejmánková, E., Carlson, E., Vrba, J., 2013. Current standard assays using artificial substrates overestimate phosphodiesterase activity. Soil Biology and Biochemistry 56, 75-79.

Sparling, G., Speir, T., Whale, K.N., 1986. Changes in microbial biomass C, ATP content, soil phosphomonoesterase and phospho-diesterase activity following air-drying of soils. Soil Biology and Biochemistry 18, 363-370.

Spohn, M., Kuzyakov, Y., 2013. Distribution of microbial- and root-derived phosphatase activities in the rhizosphere depending on $\mathrm{P}$ availability and $\mathrm{C}$ allocation - Coupling soil zymography with ${ }^{14} \mathrm{C}$ imaging. Soil Biology and Biochemistry 67, 106-113.

Tan, H., Barret, M., Mooij, M.J., Rice, O., Morrissey, J.P., Dobson, A., Griffiths, B., O'Gara, F., 2013. Longterm phosphorus fertilisation increased the diversity of the total bacterial community and the phoD phosphorus mineraliser group in pasture soils. Biology and Fertility of Soils 49, 661-672.

Tarafdar, J., Claassen, N., 1988. Organic phosphorus compounds as a phosphorus source for higher plants through the activity of phosphatases produced by plant roots and microorganisms. Biology and Fertility of Soils 5, 308-312.

Turner, B.L., 2008. Resource partitioning for soil phosphorus: a hypothesis. Journal of ecology 96, 698702.

Turner, B.L., Haygarth, P.M., 2005. Phosphatase activity in temperate pasture soils: Potential regulation of labile organic phosphorus turnover by phosphodiesterase activity. Science of the Total Environment 344, 27-36.

Turner, B.L., Papházy, M.J., Haygarth, P.M., McKelvie, I.D., 2002. Inositol phosphates in the environment. Philosophical Transactions of the Royal Society B: Biological Sciences 357, 449469.

Vance, C.P., Uhde-Stone, C., Allan, D.L., 2003. Phosphorus acquisition and use: critical adaptations by plants for securing a nonrenewable resource. New Phytologist 157, 423-447.

Viveros, A., Centeno, C., Brenes, A., Canales, R., Lozano, A., 2000. Phytase and acid phosphatase activities in plant feedstuffs. Journal of agricultural and food chemistry 48, 4009-4013.

Wallenius, K., Rita, H., Mikkonen, A., Lappi, K., Lindström, K., Hartikainen, H., Raateland, A., Niemi, R.M., 2011. Effects of land use on the level, variation and spatial structure of soil enzyme activities and bacterial communities. Soil Biology and Biochemistry 43, 1464-1473. 
Wasaki, J., Yamamura, T., Shinano, T., Osaki, M., 2003. Secreted acid phosphatase is expressed in cluster roots of lupin in response to phosphorus deficiency. Plant and Soil 248, 129-136.

Weimberg, R., Orton, W.L., 1963. Repressible acid phosphomonoesterase and constitutive pyrophosphatase of Saccharomyces mellis. Journal of bacteriology 86, 805-813.

Worsfold, P.J., Gimbert, L.J., Mankasingh, U., Omaka, O.N., Hanrahan, G., Gardolinski, P., Haygarth, P.M., Turner, B.L., Keith-Roach, M.J., McKelvie, I.D., 2005. Sampling, sample treatment and quality assurance issues for the determination of phosphorus species in natural waters and soils. Talanta $66,273-293$.

Xiao, K., Harrison, M.J., Wang, Z.-Y., 2005. Transgenic expression of a novel M. truncatula phytase gene results in improved acquisition of organic phosphorus by Arabidopsis. Planta 222, 27-36.

Yadav, R., Tarafdar, J., 2003. Phytase and phosphatase producing fungi in arid and semi-arid soils and their efficiency in hydrolyzing different organic P compounds. Soil Biology and Biochemistry 35, 745-751.

Zimmermann, P., Zardi, G., Lehmann, M., Zeder, C., Amrhein, N., Frossard, E., Bucher, M., 2003. Engineering the root-soil interface via targeted expression of a synthetic phytase gene in trichoblasts. Plant Biotechnology Journal 1, 353-360. 


\section{Tables and Figures}

Table 1 Origin, land use and general properties of the 10 soils used in this study. For details of analysis and soil origin see Jarosch et al. (2015).

\begin{tabular}{|c|c|c|c|c|c|c|c|c|c|c|c|c|}
\hline \multirow[t]{3}{*}{ Soil } & \multirow[t]{2}{*}{ Land use } & \multirow[t]{2}{*}{ Soil origin } & \multirow{2}{*}{$\begin{array}{l}\text { Location } \\
\text { Coordinates in DMS (WGS 84) }\end{array}$} & \multirow[t]{2}{*}{$\mathrm{pH}_{\mathrm{H} 2 \mathrm{O}}$} & \multicolumn{3}{|c|}{ Texture } & \multirow[t]{2}{*}{$\mathrm{C}_{\text {org }}$} & \multirow[t]{2}{*}{$\mathrm{N}_{\text {tot }}$} & \multirow[t]{2}{*}{$\mathrm{P}_{\mathrm{tot}}$} & \multirow[t]{2}{*}{$\mathrm{P}_{\text {org }}{ }^{1}$} & \multirow{2}{*}{$\begin{array}{l}\text { Porg/Ptot } \\
\text { ratio }\end{array}$} \\
\hline & & & & & clay & silt & sand & & & & & \\
\hline & & & & & \multicolumn{3}{|c|}{--------- $\mathrm{g} \mathrm{kg}^{-1}$ soil } & & ---- & \multicolumn{2}{|c|}{-----mg kg-1 soil----- } & $\%$ \\
\hline Alfisol (1) & Grassland & Australia & $35^{\circ} 10^{\prime} 34.5^{\prime \prime} \mathrm{S} ; 149^{\circ} 02^{\prime} 37.5^{\prime \prime} \mathrm{E}$ & 5.3 & 102 & 356 & 541 & 16.4 & 1.4 & $250 \pm 11$ & $59 \pm 4$ & 24 \\
\hline Cambisol (1) & Grassland & Switzerland & $47^{\circ} 26^{\prime} 33.0^{\prime \prime N} ; 8^{\circ} 40^{\prime} 51.3^{\prime \prime E}$ & 7.7 & 215 & 258 & 527 & 38.5 & 3.7 & $1327 \pm 15$ & $216 \pm 6$ & 16 \\
\hline Cambisol (2) & Grassland & Switzerland & $46^{\circ} 38^{\prime} 29.282 " \mathrm{~N} ; 8^{\circ} 28^{\prime} 28.858^{\prime \prime} \mathrm{E}$ & 4.2 & 169 & 378 & 452 & 112.2 & 8.8 & $1560 \pm 54$ & $1108 \pm 14$ & 71 \\
\hline Cambisol (3) & Grassland & Switzerland & $47^{\circ} 26^{\prime} 44.5^{\prime \prime N} ; 8^{\circ} 29^{\prime} 32.1 " \mathrm{E}$ & 5.3 & 196 & 355 & 449 & 25.2 & 2.4 & $563 \pm 23$ & $283 \pm 11$ & 50 \\
\hline Cambisol (4) & Arable & Switzerland & $47^{\circ} 26^{\prime} 19.122 " \mathrm{~N} ; 8^{\circ} 31^{\prime} 34.4496 " \mathrm{E}$ & 8.0 & 249 & 345 & 406 & 19.8 & 1.8 & $815 \pm 4$ & $224 \pm 5$ & 27 \\
\hline Lixisol (1) & Arable & Burkina Faso & $12^{\circ} 16^{\prime} 46^{\prime \prime} \mathrm{N} ; 2^{\circ} 9^{\prime} 24^{\prime \prime} \mathrm{W}$ & 5.5 & 93 & 172 & 735 & 1.6 & 0.1 & $83 \pm 4$ & $7 \pm 2$ & 8 \\
\hline Luvisol (1) & Arable & Switzerland & $47^{\circ} 25^{\prime} 36.6^{\prime \prime N} ; 8^{\circ} 31^{\prime} 08.0^{\prime \prime} \mathrm{E}$ & 5.5 & 127 & 257 & 617 & 8.2 & 0.8 & $516 \pm 2$ & $139 \pm 10$ & 27 \\
\hline Luvisol (2) & Arable & Germany & $54^{\circ} 3^{\prime} 41.47^{\prime \prime N} ; 12^{\circ} 5^{\prime} 5.59^{\prime \prime} \mathrm{E}$ & 6.2 & 96 & 194 & 710 & 8.0 & 0.7 & $505 \pm 8$ & $120 \pm 9$ & 24 \\
\hline Ferralsol (1) & Grassland & Colombia & 1²9'20.4"N; -75²6'16.7"E & 4.6 & 384 & 180 & 436 & 36.8 & 3.2 & $536 \pm 21$ & $140 \pm 6$ & 26 \\
\hline Ferralsol (2) & Arable & Madagascar & $19^{\circ} 33^{\prime} 36.1^{\prime \prime} \mathrm{S} ; 46^{\circ} 24^{\prime} 34.7^{\prime \prime} \mathrm{E}$ & 4.9 & 286 & 213 & 501 & 10.3 & 0.9 & $329 \pm 8$ & $51 \pm 5$ & 16 \\
\hline
\end{tabular}

1 in $0.25 \mathrm{M} \mathrm{NaOH}+0.05 \mathrm{M}$ EDTA extract 
Table 2 Soil:water suspensions. Concentrations of total P, molybdate-reactive P (MRP), four molybdate-unreactive P (MUP) classes detected by addition of substrate specific enzymes and the respective detection limits (DL) and quantification limits (QL) for the MUP classes for each soil. Means \pm standard deviation of two or three analytical replicates.

\begin{tabular}{|c|c|c|c|c|c|c|c|c|}
\hline \multirow[t]{3}{*}{ Soil type } & \multirow[t]{2}{*}{ Total P } & \multirow[t]{2}{*}{ MRP } & \multirow[t]{2}{*}{ MUP } & \multicolumn{3}{|c|}{ 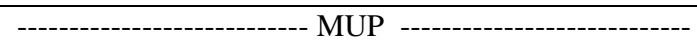 } & \multirow[t]{3}{*}{$\mathrm{DL}$} & \multirow[t]{3}{*}{ QL } \\
\hline & & & & Monoester-like P & Phytate-like $\mathrm{P}$ & Diester-like P & & \\
\hline & \multicolumn{6}{|c|}{ 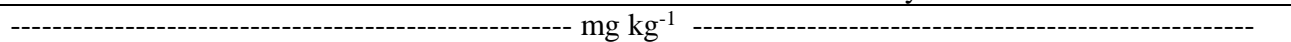 } & & \\
\hline Alfisol (1) & $8.9 \pm 1.4$ & $3.1 \pm 0.1$ & $5.9 \pm 1.3$ & nd & nd & nd & $1.0 \pm 0.0$ & $3.3 \pm 0.1$ \\
\hline Cambisol (1) & $20.5 \pm 0.2$ & $16.5 \pm 0.6$ & $3.9 \pm 0.8$ & nd & nd & nd & $4.3 \pm 0.9$ & $14.2 \pm 3.1$ \\
\hline Cambisol (2) & $48.8 \pm 3.5$ & $21.0 \pm 0.7$ & $27.8 \pm 2.9$ & nd & nd & nd & $8.8 \pm 3.8$ & $29.3 \pm 12.5$ \\
\hline Cambisol (3) & $17.2 \pm 0.1$ & $10.8 \pm 2.8$ & $6.5 \pm 2.8$ & $1.6 \pm 0.2$ & $5.0 \pm 0.7$ & $4.7 \pm 0.8$ & $0.9 \pm 0.3$ & $3.0 \pm 1.1$ \\
\hline Cambisol (4) & $14.9 \pm 2.1$ & $7.2 \pm 1.4$ & $7.7 \pm 0.7$ & nd & nd & nd & $5.7 \pm 2.1$ & $19.0 \pm 7.1$ \\
\hline Lixisol (1) & $0.9 \pm 0.4$ & $1.0 \pm 0.2$ & $0.2 \pm 0.2$ & nd & nd & nd & $0.3 \pm 0.2$ & $1.0 \pm 0.5$ \\
\hline Luvisol (1) & $20.1 \pm 0.5$ & $20.4 \pm 0.5$ & $0.3 \pm 0.4$ & $0.8 \pm 1.2^{\star}$ & nd & $1.0 \pm 0.4^{\star}$ & $1.2 \pm 0.2$ & $3.9 \pm 0.7$ \\
\hline Luvisol (2) & $15.6 \pm 1.0$ & $12.7 \pm 0.4$ & $2.9 \pm 1.1$ & nd & nd & nd & $0.9 \pm 0.9$ & $3.1 \pm 0.6$ \\
\hline Ferralsol (1) & $24.1 \pm 0.5$ & $11.6 \pm 0.8$ & $12.5 \pm 0.4$ & $1.0 \pm 0.2^{\star}$ & nd & $3.3 \pm 0.2$ & $2.2 \pm 0.8$ & $7.2 \pm 2.5$ \\
\hline Ferralsol (2) & $1.4 \pm 0.5$ & $1.1 \pm 0.0$ & $0.4 \pm 0.4$ & nd & nd & nd & $0.3 \pm 0.0$ & $0.9 \pm 0.1$ \\
\hline
\end{tabular}

nd $=$ not detected

* below DL 
Table 3 Soil:water filtrates. Concentrations of total P, molybdate-reactive P (MRP), four molybdate-unreactive P (MUP) classes detected by addition of substrate specific enzymes and the respective detection limits (DL) and quantification limits (QL) for the MUP classes. Total P and MRP were determined after filtration of soil suspensions ( $\mathrm{t} 0$ ) and after $24 \mathrm{~h}$ of incubation of filtrates in buffered solution ( $\mathrm{t} 24)$. Means \pm standard deviation of two or three analytical replicates. Values in brackets are percentages of total $\mathrm{MUP}_{\mathrm{t} 24}$.

\begin{tabular}{|c|c|c|c|c|c|c|c|c|c|c|}
\hline Soil & Total $\mathrm{P}_{\mathrm{t} 0}$ & $\mathrm{MRP}_{\mathrm{t} 0}$ & Total $\mathrm{P}_{\mathrm{t} 24}$ & $\mathrm{MRP}_{\mathrm{t} 24}$ & - & MU & -------------------- & 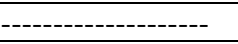 & DL & QL \\
\hline & & & & & Monoester-like P & Phytate-like P & Diester-like P & Enzyme-stable P & & \\
\hline Alfisol (1) & $1.61 \pm 0.06$ & $0.25 \pm 0.03$ & $1.40 \pm 0.28$ & $0.46 \pm 0.00^{\#}$ & $0.03 \pm 0.03(3)$ * & $0.16 \pm 0.16(18)$ & $0.09 \pm 0.09(9)$ * & $0.66 \pm 0.5(70)$ & $0.15 \pm 0.04$ & $0.50 \pm 0.13$ \\
\hline Cambisol (1) & $5.98 \pm 0.52$ & $4.53 \pm 0.11$ & $5.24 \pm 0.44$ & $4.60 \pm 0.12$ & nd & $0.24 \pm 0.17(37)$ * & nd & $0.41 \pm 0.2(63)$ & $0.40 \pm 0.08$ & $1.33 \pm 0.26$ \\
\hline Cambisol (2) & $17.8 \pm 1.1$ & $1.83 \pm 0.12$ & $14.5 \pm 0.97^{\#}$ & $7.76 \pm 0.14^{\#}$ & $2.61 \pm 0.47(39)$ & $0.57 \pm 0.40(8)$ & $0.07 \pm 0.10(1)^{*}$ & $3.45 \pm 0.8(51)$ & $0.27 \pm 0.04$ & $0.91 \pm 0.14$ \\
\hline Cambisol (3) & $6.04 \pm 0.02$ & $0.73 \pm 0.01$ & $3.64 \pm 0.07^{\#}$ & $1.63 \pm 0.01^{\#}$ & nd & $0.35 \pm 0.14(17)$ & $0.31 \pm 0.21(15)$ & $1.36 \pm 0.3(68)$ & $0.14 \pm 0.01$ & $0.48 \pm 0.05$ \\
\hline Cambisol (4) & $0.81 \pm 0.20$ & $0.18 \pm 0.03$ & $0.39 \pm 0.09$ & $0.25 \pm 0.03$ & nd & $0.16 \pm 0.16(100)^{*}$ & nd & nd & $0.18 \pm 0.01$ & $0.59 \pm 0.05$ \\
\hline Lixisol (1) & $0.52 \pm 0.10$ & $0.23 \pm 0.01$ & $0.49 \pm 0.02$ & $0.11 \pm 0.04$ & nd & nd & $0.04 \pm 0.04(9)$ * & $0.35 \pm 0(91)$ & $0.18 \pm 0.02$ & $0.59 \pm 0.07$ \\
\hline Luvisol (1) & $3.15 \pm 0.09$ & $2.32 \pm 0.07$ & $2.73 \pm 0.25$ & $2.22 \pm 0.06$ & nd & $0.28 \pm 0.24(55)$ & nd & $0.23 \pm 0.1(45)$ & $0.25 \pm 0.10$ & $0.85 \pm 0.35$ \\
\hline Luvisol (2) & $6.03 \pm 0.09$ & $5.27 \pm 0.18$ & $5.50 \pm 0.21^{\#}$ & $5.26 \pm 0.23$ & nd & $0.54 \pm 0.41(100)$ & nd & nd & $0.28 \pm 0.06$ & $0.94 \pm 0.19$ \\
\hline Ferralsol (1) & $0.61 \pm 0.31$ & $0.21 \pm 0.06$ & $0.71 \pm 0.03$ & $0.21 \pm 0.06$ & $0.04 \pm 0.04(8)$ & $0.14 \pm 0.14(27)$ * & nd & $0.33 \pm 0.1(65)$ & $0.21 \pm 0.02$ & $0.74 \pm 0.08$ \\
\hline Ferralsol (2) & $0.14 \pm 0.00$ & nd & $0.19 \pm 0.16$ & nd & $0.05 \pm 0.05(24)$ & nd & nd & $0.14 \pm 0.0(76)$ & nd & nd \\
\hline
\end{tabular}

\# = Significant difference $(\mathrm{p}<0.05)$ between time point zero (t0) and time point 24 hours $(\mathrm{t} 24)$ determined by t-test.

nd $=$ not detected

* below DL 
a)

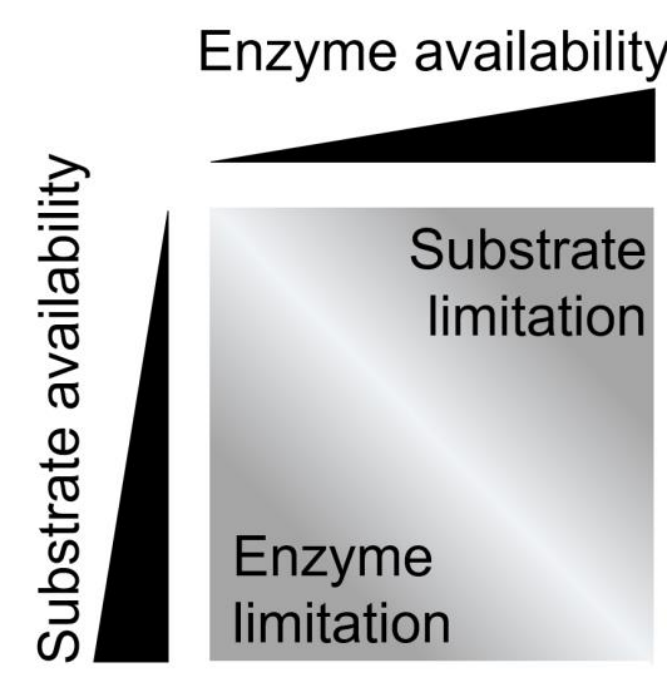

b)

Aimed quantification

\begin{tabular}{|c|c|c|}
\hline \multirow{3}{*}{$\begin{array}{l}\text { Soil:water suspension } \\
\text { or } \\
\text { Soil:water filtrate }\end{array}$} & Enzyme & $\begin{array}{l}\text { i) Sample indigenous organic } P \text { substrate } \\
\text { available for enzymatic hydrolysis }\end{array}$ \\
\hline & Substrate & $\begin{array}{l}\text { ii) Sample indigenous enzyme available for } \\
\text { hydrolysis of organic } P \text { substrate }\end{array}$ \\
\hline & $\begin{array}{l}\text { Enzyme + } \\
\text { Substrate }\end{array}$ & $\begin{array}{l}\text { iii) Control for activity/inhibition of added } \\
\text { enzymes and recovery of hydrolysis product }\end{array}$ \\
\hline & no addition & iv) Sample background ortho-P concentration \\
\hline
\end{tabular}

Figure 1 a) Soil enzyme availability (low - high) and substrate availability (low - high) jointly determine whether the mineralization of specific substrates is either substrate limited or enzyme limited. Dark-grey colours in the rectangle indicate strong limitations by one factor, while brighter colours indicate weaker or no limitation. b) Methodological approach to characterise i) the availability of specific organic P substrates by addition of substrate specific enzymes, ii) the availability of specific enzymes by addition of specific organic P substrates. Additionally, iii) a control for activity and/or inhibition of added enzymes together with the recovery of added hydrolysis product is included, with addition of specific enzymes and substrate in combination, while iv) background orthophosphate concentrations are assessed in the absence of added compounds. 
a) Suspension

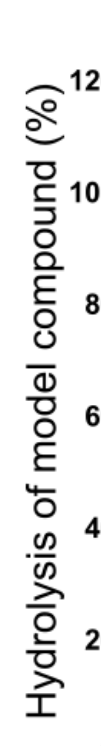

Non-phytase
phosphomonoesterase

官Enzyme added

官Enzyme added +

을

हิ

흥

苍

을

0 .

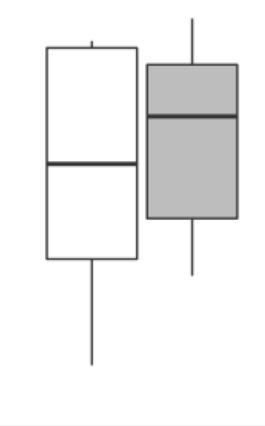

GP

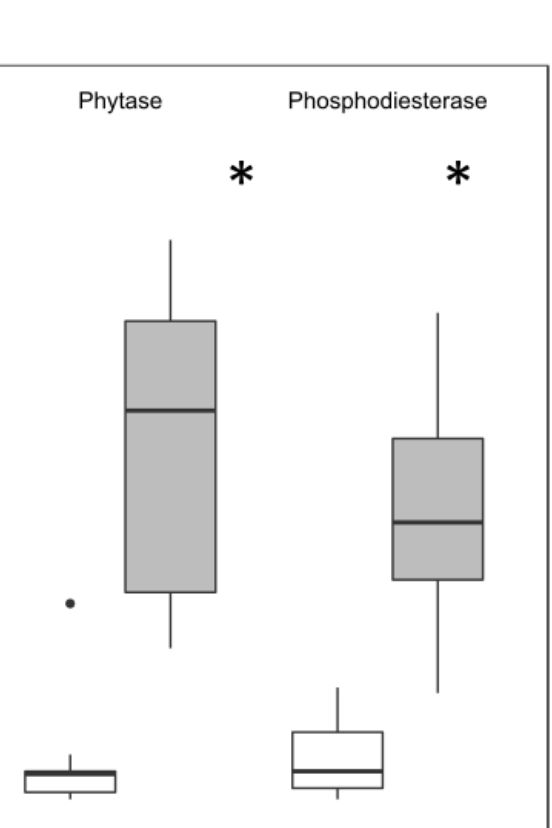

Ins6P

\section{b) Filtrate}

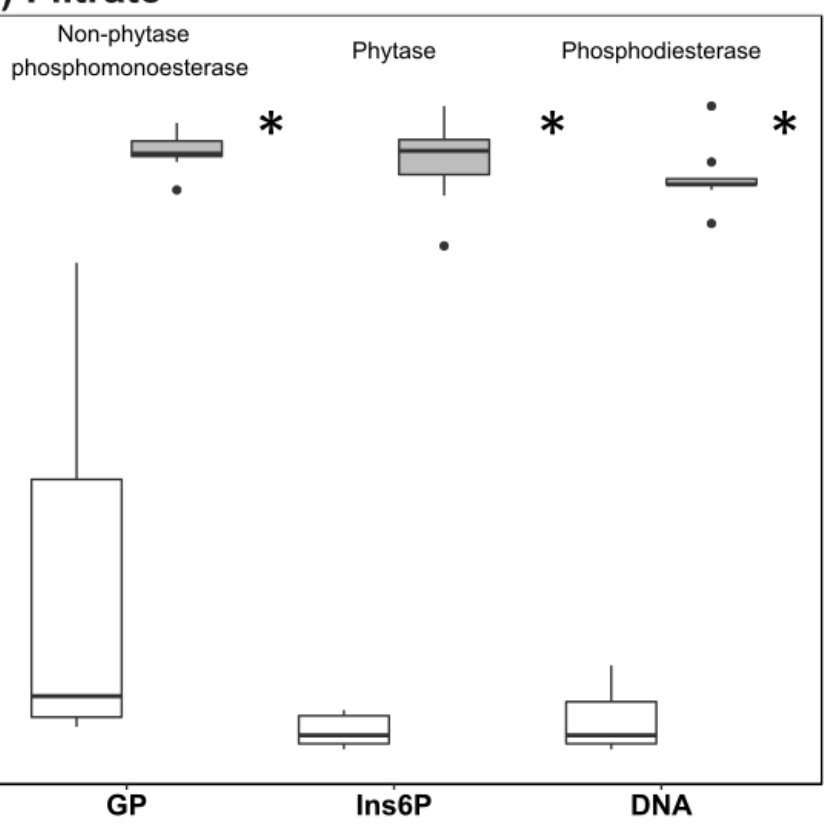

Added model compound

Figure 2 Hydrolysis of organic P model compounds in the absence (Enzyme added - ) or presence (Enzyme added + ) of added enzymes in a) soil:water suspensions and b) soil:water filtrates. Each box plot is composed of the mean values ( $2-3$ replicates each) of ten soils. The lower and upper hinge of each boxplot corresponds to the first and third quantiles, the line in the boxplot indicates the median value. Lower and upper whiskers extend to the lowest and highest value to 1.5 times the inter-quartile range (IQR), while points indicate values lower or higher to 1.5 times the IQR. Model compounds used and respective enzymes added were glycerol phosphate (GP; a non-phytate phosphomonoester) + non-phytase phosphomonoesterase, phytic acid sodium salt hydrate (Ins6P; phytate phosphomonoester) + phytase and desoxyribonucleic acid (DNA, a phosphodiester) + phosphodiesterase in combination with non-phytase phosphomonoesterase. Asterisk $(*)$ denotes significant differences between enzyme treated and untreated model compounds ( $\mathrm{p}<0.01$, Kruskal-Wallis test). 


\begin{tabular}{|c|c|c|c|c|c|c|c|c|}
\hline \multirow{2}{*}{ Substrate / enzyme } & \multirow{2}{*}{$\begin{array}{l}\text { Hydrolytic enzyme } \\
\text { reaction }\end{array}$} & \multicolumn{3}{|c|}{ Substrate properties in soil } & \multicolumn{3}{|l|}{ Enzyme properties in soil } & \multirow{2}{*}{$\begin{array}{l}\text { Limiting factor } \\
\text { for organic } P \\
\text { hydrolysis }\end{array}$} \\
\hline & & Production & Stabilization & Availability & Production Stabilization & Max.activ. & Availability & \\
\hline $\begin{array}{l}\text { Phosphomonoester othe } \\
\text { than phytate / } \\
\text { Non-phytase phospho- } \\
\text { monoesterase }\end{array}$ & $\mathrm{R}-\mathrm{P} \rightarrow \mathrm{R}-\mathrm{OH}+\mathrm{P}$ & & & & & & & $\begin{array}{l}\text { Substrate } \\
\text { limited }\end{array}$ \\
\hline Phytate / Phytase & $\begin{array}{c}\mathrm{HO} \\
+6 \mathrm{P}\end{array}$ & & & & & & & $\begin{array}{l}\text { Enzyme } \\
\text { limited }\end{array}$ \\
\hline $\begin{array}{l}\text { Phosphodiester / } \\
\text { Phosphodiesterase }\end{array}$ & $\mathrm{R}-\mathrm{P}-\mathrm{R} \rightarrow \mathrm{R}-\mathrm{OH}+\mathrm{P}-\mathrm{R}$ & & & & & $?$ & & $\begin{array}{l}\text { Enzyme } \\
\text { limited }\end{array}$ \\
\hline
\end{tabular}

Figure 3 Hydrolytic reaction for three organic P substrates and their respective hydrolysing enzymes and estimation of the relative proportion of factors influencing substrate availability and enzyme availability in soil:water suspensions. The importance of different factors (production, stabilization, maximum catalytic activity (Max.activ.) and resulting availability were derived from the present study as well as from the respective references in section 4.2 and section 4.3 Box sizes are an estimation of the relative effect size for each factor per column (low, medium, high); sizes do not directly equate to actual values. 


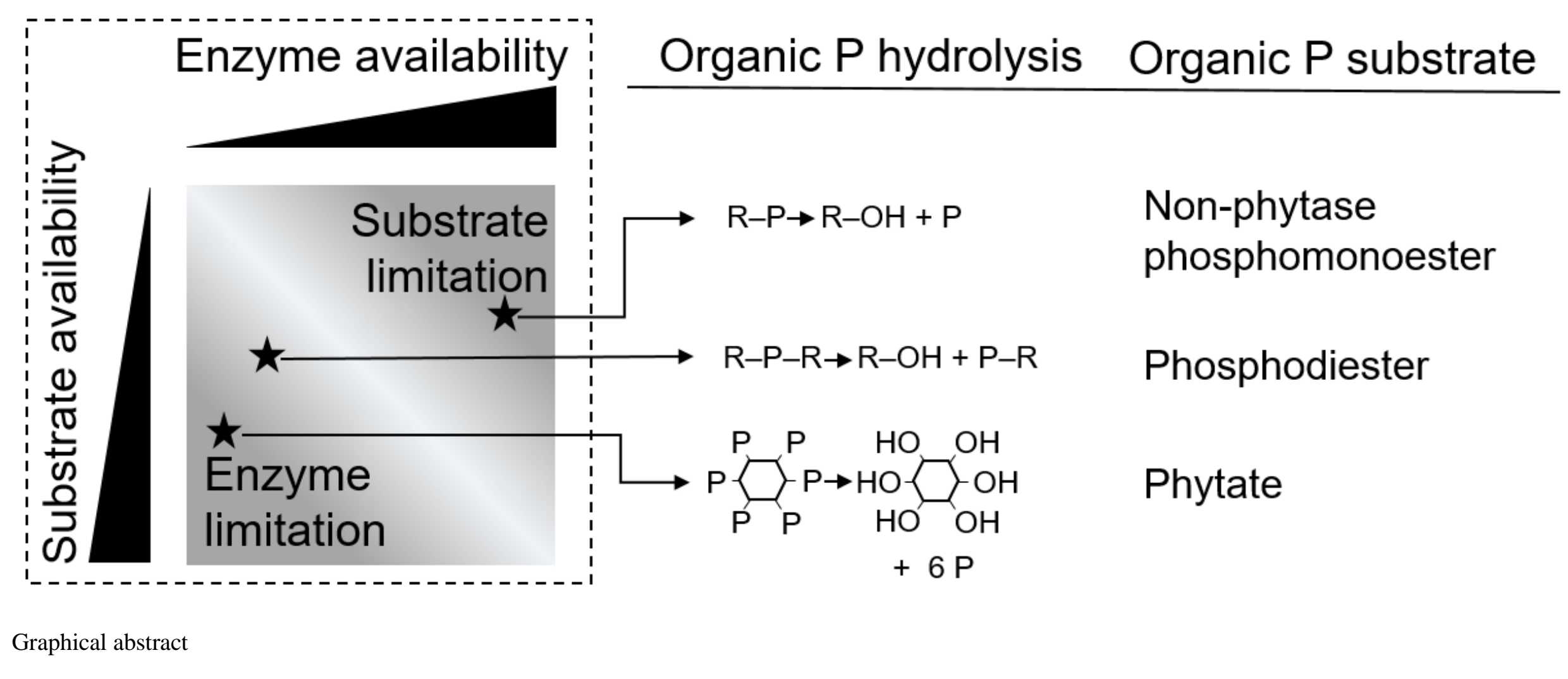


